EXTENDED REPORT

\title{
Unilateral electronegative ERG of non-vascular aetiology
}

\author{
A G Robson, E C Richardson, A H C Koh, C E Pavesio, P G Hykin, A Calcagni, E M Graham, \\ G E Holder
}

See end of article for authors' affiliations

Correspondence to:

Dr G E Holder,

Electrophysiology,

Moorfields Eye Hospital,

162 City Road, London

ECIV 2PD, UK; graham.

holder@moorfields.nhs.uk

Accepted for publication 2 August 2005
Br J Ophthalmol 2005;89:1620-1626. doi: 10.1136/bjo.2005.071357

Background: Full field and pattern electroretinograms (ERG, PERG) are performed to assess generalised retinal function and macular function, respectively. An (electro) negative full field ERG usually describes an ISCEV standard maximal response in which the b-wave is smaller than a normal or minimally reduced awave and indicates dysfunction that is post-phototransduction. The most common cause of a unilateral negative ERG is central retinal artery occlusion (CRAO) or birdshot chorioretinopathy (BCR). This study examines the clinical and electrophysiological features of patients with unilateral negative ERG who do not have CRAO or BCR.

Methods: 12 patients were ascertained with a unilateral negative ERG in whom a vascular aetiology and BCR were excluded. Most presented with symptoms of central retinal dysfunction. In 11 of the 12 patients additional long duration photopic stimuli were used to test cone system ON and OFF responses.

Results: All 12 patients had unilateral electronegative bright flash full field ERGs indicating total or relative preservation of rod photoreceptor function, but dysfunction post-phototransduction. Seven of these patients had non-specific inflammatory changes in the eye with the negative ERG. Six patients, including five with inflammatory signs, had involvement of the cone $\mathrm{ON}$ response with complete preservation of cone OFF responses. A further three patients showed evidence of cone $\mathrm{ON}$ response abnormality with less severe OFF response involvement.

Conclusion: The ERGs in this heterogeneous group of patients predominantly showed post-phototransduction involvement of the ON pathways. Sparing of the cone OFF response was often observed. The majority of patients had signs of previous inflammation and it is speculated that these highly unusual unilateral changes may be mediated via an autoimmune mechanism.
A n electronegative electroretinogram (ERG) describes a full field ERG in which the b-wave is smaller than the normal or minimally attenuated a-wave. It is usually best seen in the rod dominated maximal ERG following stimulation with a bright flash under scotopic conditions, ${ }^{1-3}$ although sometimes manifest in cone derived ERGs recorded under photopic conditions as a reduced b:a ratio. ${ }^{45}$ A selectively reduced b-wave indicates impaired retinal function which is post-phototransduction, usually post-receptoral, and may be associated with a number of congenital and acquired conditions such as $\mathrm{X}$ linked juvenile retinoschisis, ${ }^{67}$ Congenital stationary night blindness (CSNB), ${ }^{389}$ central retinal artery occlusion (CRAO), ${ }^{10-12}$ birdshot chorioretinopathy (BCR), ${ }^{13-15}$ melanoma associated retinopathy (MAR), ${ }^{16}{ }^{17}$ retinal toxicity, ${ }^{2}{ }^{18}{ }^{19}$ and a number of other less common disorders (see table 1).

Unilateral electronegative ERGs are commonly associated with $\mathrm{CRAO}^{10-12}$ and may occur in some patients with BCR. $^{3}{ }^{1520}$ A previous retrospective review of 2640 patients from this unit ${ }^{21}$ revealed 128 with negative ERGs (table 1). There were 25 undiagnosed cases, of which seven had unilateral electronegative ERGs. As an extension of that audit, the present study examines in detail the clinical and electrophysiological features of 12 patients with unilateral electronegative ERG in whom a vascular aetiology and BCR have been excluded. These patients have been reviewed in an attempt to ascertain common features and elucidate underlying mechanisms.

\section{MATERIALS AND METHODS}

Twelve patients form the basis of this report. Seven had previously been identified as having unilateral electronegative ERGs as part of an earlier study. ${ }^{21}$ The clinical notes were

\begin{tabular}{lc} 
Table 1 Causes of electronegative ERG (after Koh et $a^{21}$ ) \\
\hline & $\begin{array}{c}\text { Number of } \\
\text { patients }\end{array}$ \\
\hline X linked juvenile retinoschisis & 19 \\
Congenital stationary night blindness & 17 \\
Central retinal artery occlusion & 13 \\
Birdshot chorioretinopathy & 7 \\
Toxic retinopathy (quinine, vincristine, vigabatrin) & 5 \\
Melanoma associated retinopathy & 4 \\
Batten disease & 1 \\
Unspecified inflammatory retinopathy & 3 \\
Photoreceptor dystrophy & $34^{*}$ \\
Undiagnosed & 25 \\
Total & 128
\end{tabular}

*Additional abnormal a-wave reduction.

examined and any relevant follow up data and investigation results were reviewed. A vascular aetiology and birdshot chorioretinopathy were excluded in all patients on this basis.

Full field ERGs were performed using extended testing protocols incorporating the ISCEV (International Society for Clinical Electrophysiology of Vision) minimum standard ${ }^{22}$ in order to assess generalised retinal function. ${ }^{12}$ The minimum protocol incorporates the rod specific and standard bright flash ERGs, both recorded after a minimum of 20 minutes
Abbreviations: ANA, antinuclear antibody; $B C R$, birdshot chorioretinopathy; CAR, carcinoma associated retinopathy; CSNB, congenital stationary night blindness; CRAO, central retinal artery occlusion; EOG, electro-oculogram; ERG, electroretinograms; FFA, fluorescein angiography; ISCEV, International Society for Clinical Electrophysiology of Vision; MAR, melanoma associated retinopathy; PERG, pattern electroretinogram; RAPD, relative afferent pupillary defect 
dark adaptation, and the photopic $30 \mathrm{~Hz}$ flicker and transient photopic ERGs, both recorded after a standard period and intensity of light adaptation. A stimulus $0.6 \mathrm{log}$ units greater than the ISCEV standard flash was also used, better to demonstrate the a-wave, as suggested in the recent revision of the ISCEV standard for ERG. ${ }^{22}$ Pupils were dilated before full field ERG testing using tropicamide (1\%) and phenylephrine hydrochloride (2.5\%). ISCEV standard pattern ERG (PERG) was performed ${ }^{23}$ before mydriasis and the P50 component, partly originating in structures anterior to the retinal ganglion cells and driven by the macular photoreceptors, was used to assess macular function. ${ }^{3}$ In most cases, ISCEV standard electro-oculogram (EOG) was also performed $^{24}$ in order to assess the function of the retinal pigment epithelium/photoreceptor interface. ${ }^{25}$ Long duration ON-OFF ERGs were used to assess post-receptoral cone $\mathrm{ON}$ and OFF pathways, predominantly arising in relation to depolarising and hyperpolarising bipolar cell function. ${ }^{17} 26$

Table 2 Summary of clinical findings in all patients

\begin{tabular}{|c|c|c|c|c|c|c|c|c|c|}
\hline Case & Sex & Age & Fundi at presentation* & $\begin{array}{l}\text { Visual } \\
\text { acuity }\end{array}$ & RAPD & $\begin{array}{l}\text { Signs of } \\
\text { inflammation }\end{array}$ & Field defect & $\begin{array}{l}\text { Presenting } \\
\text { symptoms }\end{array}$ & Brief clinical history \\
\hline \multirow[t]{2}{*}{1} & $\mathrm{~F}$ & 58 & $\begin{array}{l}\text { RE: Juxtafoveal } \\
\text { telangectasia }\end{array}$ & $6 / 9$ & - & - & $\begin{array}{l}\text { RE: small nasal } \\
\text { scotoma }\end{array}$ & $\begin{array}{l}\text { LE: } \\
\text { metamorphopsia } \\
\text { and loss of } \\
\text { colour vision }\end{array}$ & $\begin{array}{l}\text { Breast carcinoma and } \\
\text { mastectomy } 1 \text { year after } \\
\text { presentation. Sudden loss of } \\
\text { colour vision in RE } 6 \text { years } \\
\text { later. }\end{array}$ \\
\hline & & & $\begin{array}{l}\text { LE: Juxtafoveal } \\
\text { hypertrophic laser scar }\end{array}$ & $6 / 12$ & & - & $\begin{array}{l}\text { LE: small nasal } \\
\text { scotoma relating to } \\
\text { laser scar }\end{array}$ & & \\
\hline \multirow[t]{2}{*}{2} & M & 62 & RE: normal & $6 / 5$ & - & - & $\begin{array}{l}\text { RE: mild temporal } \\
\text { deficit }\end{array}$ & $\begin{array}{l}\text { RE: colour vision } \\
\text { loss }\end{array}$ & $\begin{array}{l}\text { History of cutaneous } \\
\text { melanoma. }\end{array}$ \\
\hline & & & LE: normal & $6 / 5$ & & - & $\begin{array}{l}\text { LE: mild inferior } \\
\text { temporal loss }\end{array}$ & & \\
\hline \multirow[t]{2}{*}{3} & $\mathrm{~F}$ & 46 & RE: normal & $6 / 12$ & + & - & $\begin{array}{l}\text { RE: Superionasal } \\
\text { deficit }\end{array}$ & $\begin{array}{l}\text { RE: intermittent } \\
\text { visual loss }\end{array}$ & \\
\hline & & & LE: normal & $6 / 9$ & & - & & & \\
\hline \multirow[t]{2}{*}{4} & M & 33 & $\begin{array}{l}\text { RE: small juxtaoveal } \\
\text { cyst. }\end{array}$ & $6 / 5$ & + & - & & & $\begin{array}{l}\text { Chicken pox } 7 \text { months prior } \\
\text { to symptoms. }\end{array}$ \\
\hline & & & $\begin{array}{l}\text { LE: inferior chorioretinal } \\
\text { atrophy, attenuated } \\
\text { arterioles, venous } \\
\text { bleeding, granular } \\
\text { fovea. Vitreous cells }\end{array}$ & $6 / 60$ & & LE: vitreous cells & $\begin{array}{l}\text { LE: dense central } \\
\text { scotoma }\end{array}$ & $\begin{array}{l}\text { LE: sudden visual } \\
\text { loss }\end{array}$ & \\
\hline \multirow[t]{2}{*}{5} & M & 59 & RE: normal & $6 / 6$ & + & - & & & \\
\hline & & & LE: cupped disc & $6 / 6$ & & - & LE: Inferior & $\begin{array}{l}\text { LE: faded colour } \\
\text { vision }\end{array}$ & \\
\hline \multirow[t]{2}{*}{6} & M & 40 & RE: pale disc & $6 / 18$ & + & RE: vitreous cells & RE: central+ & $\begin{array}{l}\text { LE: visual } \\
\text { disturbance }\end{array}$ & $\begin{array}{l}12 \text { year history of pan- } \\
\text { uveitis. } 2-3 \text { years after } \\
\text { presentation reported colour } \\
\text { vision loss RE. } 4 \text { years later } \\
\text { LE capsulotomy. }\end{array}$ \\
\hline & & & LE: normal & $6 / 12$ & & $\begin{array}{l}\text { LE: cells+, flare }+ \text {, } \\
\text { vitreous cells }+\end{array}$ & LE: central & & \\
\hline \multirow[t]{2}{*}{7} & $\mathrm{~F}$ & 30 & RE: CMO, snowballs & $6 / 9$ & - & $\begin{array}{l}\text { RE: uveitis and } \\
\text { scleritis }\end{array}$ & RE: Constricted & $\begin{array}{l}\text { RE: floaters and } \\
\text { reduced vision }\end{array}$ & $\begin{array}{l}\text { RE photopsia } 2 \text { years after } \\
\text { presentation and RE } \\
\text { nyctalopia } 5 \text { months later. }\end{array}$ \\
\hline & & & LE: normal & $6 / 6$ & & & & & \\
\hline 8 & $\mathrm{~F}$ & 25 & $\begin{array}{l}\text { RE: swollen disc } \\
\text { multiple foci of atrophy } \\
\text { LE: normal }\end{array}$ & $\begin{array}{l}6 / 12 \\
6 / 5\end{array}$ & + & RE: vitritis & $\begin{array}{l}\text { RE: enlarged blind } \\
\text { spot }\end{array}$ & $\begin{array}{l}\text { RE: sudden } \\
\text { visual loss }\end{array}$ & v \\
\hline \multirow[t]{2}{*}{9} & $\mathrm{~F}$ & 42 & $\begin{array}{l}\text { RE: punched out scars } \\
\text { at posterior pole. }\end{array}$ & $6 / 6$ & - & - & - & LE: reduced vision & $\begin{array}{l}\text { One month after presentation } \\
\text { developed photopsia RE. } \\
\text { Initially diagnosed with PIC. }\end{array}$ \\
\hline & & & $\begin{array}{l}\text { LE: punched out scars } \\
\text { at posterior pole and } \\
\text { subfoveal CNV. }\end{array}$ & $6 / 60$ & & - & & & \\
\hline \multirow[t]{2}{*}{10} & M & 31 & $\begin{array}{l}\text { RE: swollen disc, } \\
\text { chorioretinal scars, } \\
\text { CMO }\end{array}$ & $6 / 60$ & - & RE: vitreous cells & $\begin{array}{l}\text { RE: enlarged blind } \\
\text { spot }\end{array}$ & $\begin{array}{l}\text { RE: reduced } \\
\text { vision }\end{array}$ & $\begin{array}{l}4 \text { years after presentation } \\
\text { had vitreous cells and vessel } \\
\text { sheathing bilaterally. RE } \\
\text { developed ERM. LE CMO } \\
\text { and photopsia. }\end{array}$ \\
\hline & & & $\begin{array}{l}\text { LE: swollen disc, } \\
\text { chorioretinal scars. }\end{array}$ & $6 / 5$ & & - & $\begin{array}{l}\text { LE: enlarged blind } \\
\text { spot }\end{array}$ & & \\
\hline \multirow[t]{2}{*}{11} & M & 45 & RE: normal & $6 / 5$ & - & - & - & $\begin{array}{l}\text { LE: reduced vision } \\
\text { and red } \\
\text { desaturation }\end{array}$ & \\
\hline & & & LE: normal & $6 / 5$ & & - & & & \\
\hline \multirow[t]{2}{*}{12} & $\mathrm{~F}$ & 54 & $\begin{array}{l}\text { RE: CMO. Inferior } \\
\text { chorioretinal lesions, } \\
\text { snowballs, haze }\end{array}$ & $6 / 6$ & - & RE: cells+ & $\begin{array}{l}\text { RE: small central } \\
\text { defect }\end{array}$ & RE: nyctalopia & $\begin{array}{l}10 \text { year history of bilateral } \\
\text { intermittent uveitis with } 4 \\
\text { month exacerbation RE }>\text { LE. }\end{array}$ \\
\hline & & & $\begin{array}{l}\text { LE: chorioretinal lesions } \\
\text { and scar related to } \\
\text { laser treatment for } \\
\text { CNV, snowballs }\end{array}$ & $6 / 6$ & & LE: cells & $\begin{array}{l}\text { LE: small defect on } \\
\text { left related to laser } \\
\text { scar }\end{array}$ & & \\
\hline
\end{tabular}

$\mathrm{RE}$, right eye; LE, left eye; CMO, cystoid macular oedema; CNV, choroidal neovascularisation, ERM: epiretinal membrane; PIC, punctate inner choroidopathy. *Eyes with negative ERG in bold. 
Table 3 Summary of electrophysiology and colour vision testing

\begin{tabular}{|c|c|c|c|c|c|c|c|c|c|c|c|}
\hline & Eye & $\begin{array}{l}\text { Pattern } \\
\text { ERG P50 }\end{array}$ & $\begin{array}{l}\text { Scotopic } \\
\text { rod } \\
\text { ERG }\end{array}$ & $\begin{array}{l}\text { Scotopic } \\
\text { maximal } \\
\text { ERG }\end{array}$ & OPs & $\begin{array}{l}\text { Photopic } \\
\text { transient } \\
\text { ERG }\end{array}$ & $\begin{array}{l}\text { Photopic } \\
30 \mathrm{~Hz} \\
\text { ERG }\end{array}$ & $\begin{array}{l}\text { ON } \\
\text { b-wave }\end{array}$ & $\begin{array}{l}\text { OFF } \\
\text { d-wave }\end{array}$ & EOG & CCS \\
\hline \multirow[t]{2}{*}{1} & RE & $\mathrm{N}$ & $N$ & $\mathrm{~N}$ & $\mathrm{~N}$ & $N$ & $\mathrm{~N}$ & $n / p$ & $n / p$ & $\mathrm{~N}$ & $\mathrm{~N}$ \\
\hline & LE & A & A & A (-ve) & A & A & A & $n / p$ & $n / p$ & $\mathrm{~N}$ & A \\
\hline \multirow[t]{2}{*}{2} & RE & A & A & A (-ve) & A & A & A & A++ & $\mathrm{A}+$ & $n / p$ & A \\
\hline & $\mathrm{LE}$ & $\mathrm{N}$ & $\mathrm{N}$ & $\mathrm{N}$ & $\hat{N}$ & $\mathrm{~N}$ & $\ddot{N}$ & $\mathrm{~N}$ & $\mathrm{~N}$ & $\mathrm{n} / \mathrm{p}$ & $\mathrm{N}$ \\
\hline \multirow[t]{2}{*}{3} & $\mathrm{RE}$ & A & A & A (-ve) & A & A & A & $\mathrm{A}_{+}$ & $A($ mild $)$ & $\mathrm{N}$ & A \\
\hline & $\mathrm{LE}$ & $\mathrm{N}$ & $\hat{N}$ & $\mathrm{~N}$ & $\hat{N}$ & $\mathrm{~N}$ & $\ddot{N}$ & $\mathrm{~N}$ & $\mathrm{~N}$ & $\mathrm{~N}$ & $\mathrm{~N}$ \\
\hline \multirow[t]{2}{*}{4} & $\mathrm{RE}$ & $\mathrm{N}$ & $\mathrm{N}$ & $\mathrm{N}$ & $\mathrm{N}$ & $\mathrm{N}$ & $\mathrm{N}$ & $\mathrm{N}$ & $\mathrm{N}$ & $\mathrm{N}$ & $\mathrm{N}$ \\
\hline & LE & A & A & A (-ve) & A & A & A & A+ & A & A & A \\
\hline \multirow[t]{2}{*}{5} & $\mathrm{RE}$ & $\mathrm{N}$ & $\mathrm{N}$ & $\mathrm{N}$ & $\mathrm{N}$ & $\mathrm{N}$ & $\hat{N}$ & $\mathrm{~N}$ & $\mathrm{~N}$ & $\mathrm{~N}$ & $\mathrm{~N}$ \\
\hline & LE & A & A & A (-ve) & A & A (-ve) & A & $\mathrm{A}++$ & A+ & A & A \\
\hline \multirow[t]{2}{*}{6} & $\mathrm{RE}$ & A & $\mathrm{N}$ & $\mathrm{N}$ & $\mathrm{N}$ & $\mathrm{N}$ & $\hat{N}$ & $\mathrm{n} / \mathrm{p}$ & $n / p$ & $n / p$ & A \\
\hline & LE & A & A & A (-ve) & A & A (low b:a) & A & A(-ve) & $\mathrm{A}+$ & $n / p$ & A \\
\hline \multirow[t]{2}{*}{7} & RE & A & A & A (-ve) & A & A & A & A(-ve) & $\mathrm{N}$ & $\mathrm{N}$ & A \\
\hline & $\mathrm{LE}$ & $\mathrm{N}$ & $\mathrm{N}$ & $\mathrm{N}$ & $\mathrm{N}$ & $\mathrm{N}$ & $\ddot{N}$ & $\mathrm{~N}$ & $n / r$ & $\mathrm{~N}$ & $\ddot{N}$ \\
\hline \multirow[t]{2}{*}{8} & RE & A & A & A (-ve) & A & A & A & A(-ve) & $\mathrm{N}$ & A & A \\
\hline & $\mathrm{LE}$ & $\mathrm{N}$ & $\mathrm{N}$ & $\mathrm{N}$ & $\mathrm{N}$ & $\mathrm{N}$ & $\ddot{N}$ & $\mathrm{~N}$ & $\mathrm{~N}$ & $\ddot{N}$ & $\ddot{N}$ \\
\hline \multirow[t]{2}{*}{9} & $\mathrm{RE}$ & $\mathrm{N}$ & $\mathrm{N}$ & A & $\mathrm{N}$ & $\mathrm{N}$ & $\mathrm{N}$ & $N$ & N & $\mathrm{N}$ & $\mathrm{N}$ \\
\hline & LE & A & A & A (-ve) & A & A & A & A & $N$ & $\mathrm{~N}$ & A \\
\hline \multirow[t]{2}{*}{10} & $\mathrm{RE}$ & $A($ now $N)$ & A & A & A & A & A & $\mathrm{A}$ & A (mild) & A & A \\
\hline & LE & A & A & A (-ve) & A & A & A & A(-ve) & $\mathrm{N}$ & A & $\mathrm{N}$ \\
\hline \multirow[t]{2}{*}{11} & $\mathrm{RE}$ & $\hat{N}$ & $\hat{N}$ & $\mathrm{~N}$ & $\mathrm{~N}$ & $\mathrm{~N}$ & $\hat{N}$ & $\mathrm{~N}$ & $\mathrm{~N}$ & $\mathrm{~N}$ & $n / p$ \\
\hline & LE & A & A & A (-ve) & A & A & A & A(-ve) & At & $\mathrm{N}$ & \\
\hline \multirow[t]{2}{*}{12} & $\mathrm{RE}$ & A & $\mathrm{A}_{+}$ & A(-ve) & A & A & A & A(-ve) & $\mathrm{N}$ & $\mathrm{N}$ & $n / p$ \\
\hline & $\mathrm{LE}$ & A & A & $\mathrm{N}$ & $\mathrm{N}$ & A & A & $\mathrm{N}$ & $\mathrm{N}$ & $\mathrm{N}$ & \\
\hline
\end{tabular}

Eyes with electronegative ERGs in bold. Ops, oscillatory potentials; EOG, electro-oculogram; CCS, colour contrast sensitivity. A: abnormal. At: very abnormal. At+: extremely abnormal. $\mathrm{N}$ : normal. $\mathrm{n} / \mathrm{p}$ : not performed. $\mathrm{n} / \mathrm{r}$ : not reliable. -ve: electronegative (relatively normal $\mathrm{a}$-wave that is larger than the b-wave). Low b:a: low b-wave to a-wave ratio

The LED stimulator has been previously described.$^{27}$ In brief, the duration of the amber stimulus was $150 \mathrm{~ms}$ or $200 \mathrm{~ms}$. Stimulus luminance was $560 \mathrm{~cd} / \mathrm{m}^{2}$ with a green background of $160 \mathrm{~cd} / \mathrm{m}^{2}$, suitable to suppress rod function. ${ }^{28}$

Colour contrast thresholds along isoluminant protan, deutan, and tritan axes were determined psychophysically in all patients using the Arden colour contrast sensitivity system..$^{29}$

\section{RESULTS}

\section{Group findings}

The clinical and electrophysiological findings in the 12 patients are summarised in tables 2, 3, and 4. Within this group, seven had clinical signs of inflammation. These signs ranged from fundus scarring in the absence of vitritis (case 9) to panuveitis (case 8). Abnormality of visual fields was also a common finding, seen in 10/12 cases. This was, however, variable in its extent.

Maximal scotopic ERGs from all patients showed an electronegative ERG in one eye, consistent with postphototransduction dysfunction affecting the rod system. Full field ERGs were additionally abnormal in the other eye of three cases, indicating dysfunction at the level of the photoreceptors (cases 9 and 10) or confined to the cone system (case 12, see below). Fellow eyes of nine patients had normal full field ERGs. The cone ON responses were affected more than the OFF responses in 9/11 patients, including 6/7 patients with signs of inflammatory disease. Inflammatory signs were confined to the eye with an electronegative ERG in three patients (cases 4,7 , and 8 ) or occurred bilaterally but more severely in the eye with an electronegative ERG (cases 9 and 12). In one case there was evidence of bilateral

Table 4 ERG and clinical follow up

\begin{tabular}{|c|c|c|c|}
\hline Case & $\begin{array}{l}\text { No of } \\
\text { ERGs* }\end{array}$ & ERG changes & Clinical changes since initial ERG \\
\hline 1 & $3(50)$ & Stable & Sudden loss of colour vision in RE 6 years later. \\
\hline 2 & 1 & - & Not available \\
\hline 3 & $3(63)$ & Stable & $\begin{array}{l}\text { VA fell from } 6 / 12 \text { to } 6 / 36 \text { over } 5 \text { years. Developed } \\
\text { transient episodes of loss of vision. Fundus remains } \\
\text { normal }\end{array}$ \\
\hline 4 & $9(69)$ & See text & \\
\hline 5 & $3(22)$ & $\begin{array}{l}\text { Mild deterioration in cone } \\
\text { ERGs and PERG }\end{array}$ & $\begin{array}{l}\text { Mild deterioration in colour contrast sensitivity over } 2 \\
\text { years }\end{array}$ \\
\hline 6 & 1 & - & $\begin{array}{l}\text { Persistent inflammation, sudden reduction in VA LE } \\
\text { from } 6 / 12 \text { to } 6 / 36 \text { after } 1 \text { year associated with } \\
\text { episode of vitritis without } C M O \text {. Vitritis settled with } \\
\text { steroids but VA unchanged } 1 \text { year later }\end{array}$ \\
\hline 7 & $2(10)$ & See text & \\
\hline 8 & $5(24)$ & Stable & $\begin{array}{l}\text { Right lens opacity developed over } 5 \text { years, otherwise } \\
\text { stable }\end{array}$ \\
\hline 9 & 1 & - & Stable since last tested 3 years ago \\
\hline 10 & $8(67)$ & See text & \\
\hline 11 & $2(10)$ & Stable & Stable over 10 months \\
\hline 12 & 1 & - & - \\
\hline
\end{tabular}



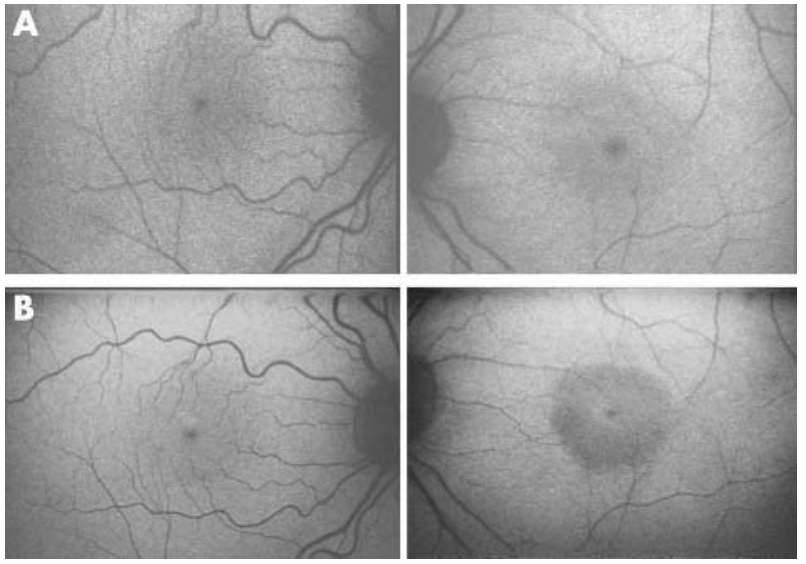

Figure 1 Fundus autofluorescence images of case 4 were initially normal bilaterally $(A)$ but 2 years later revealed a low density area in the left eye (B).

inflammatory eye disease associated with bilateral but asymmetric ERG abnormalities (case 10).

Pattern ERG P50 components were reduced unilaterally in all eyes with an electronegative ERG and were reduced bilaterally in three cases, consistent with macular dysfunction. Colour contrast thresholds were elevated in the affected eye of 9/10 patients, bilaterally in one (case 6).

Retinal function was monitored in eight patients over periods of between 10 months and 69 months, using serial ERGs. There was mild but progressive photopic ERG deterioration in case 4 (see below) and mild non-specific worsening of full field ERGs in cases 5 and 10 (table 4 and below). Five patients showed no significant electrophysiological change between recordings. In total, $7 / 10$ patients showed evidence of clinical or subjective deterioration since ERGs were initially performed (table 4): in three of these cases abnormalities related to the development of cataract (case 8) or mild to moderate inflammatory changes (cases 6 and 7 , see below). One patient with a history of bilateral chronic uveitis developed unilateral night blindness following a recurrence of inflammation in the affected eye (case 12, see detailed history below).

Four illustrative cases are presented in more detail.

\section{Case 4}

A 33 year old man presented with sudden painless loss of left visual acuity. His VA was 6/60 and he had some very mild peripheral inferior chorioretinal atrophy with a few vitreous cells. There was a left relative afferent pupillary defect (RAPD). Fields showed a dense left central scotoma. Colour contrast thresholds were profoundly elevated on the left, normal on the right. Antinuclear antibody (ANA) was weakly positive but all other tests for lupus were negative. Oral immunosuppression with steroids and azathioprine had no effect. Fluorescein angiography (FFA) showed mild leakage from one inferonasal vessel. Autofluorescence imaging showed no definite abnormality but 2 years later showed central hypofluorescence (fig 1).

ERGs were normal on the right (not shown). On the left, the scotopic rod ERG was subnormal and the maximal ERG was mildly electronegative, indicating post-phototransduction or post-receptoral rod system dysfunction (fig 2). Photopic ERG a-wave and b-wave amplitudes and $30 \mathrm{~Hz}$ flicker ERGs were severely reduced and showed mild to moderate delay and the ON b-wave and OFF d-waves were reduced in keeping with generalised cone system dysfunction. The PERG on the left was undetectable, consistent with severe macular dysfunction. Serial electrophysiological studies revealed mild but progressive deterioration of photopic full field ERGs on the left over a 5 year period. The patient remained clinically stable.

\section{Case 7}

A 30 year old woman presented with right acuity loss and floaters. Right VA was 6/9. There was cystoid macular oedema and vitreous snowballs on the right, and a diagnosis of intermediate uveitis was made. There was tritan threshold elevation on colour contrast sensitivity testing. Investigations, including HLA-A29, were negative. She developed photopsia 2 years later, with right visual field constriction, and was re-referred. FFA added no new information. There was no RAPD. She developed nyctalopia on the right 5 months later.
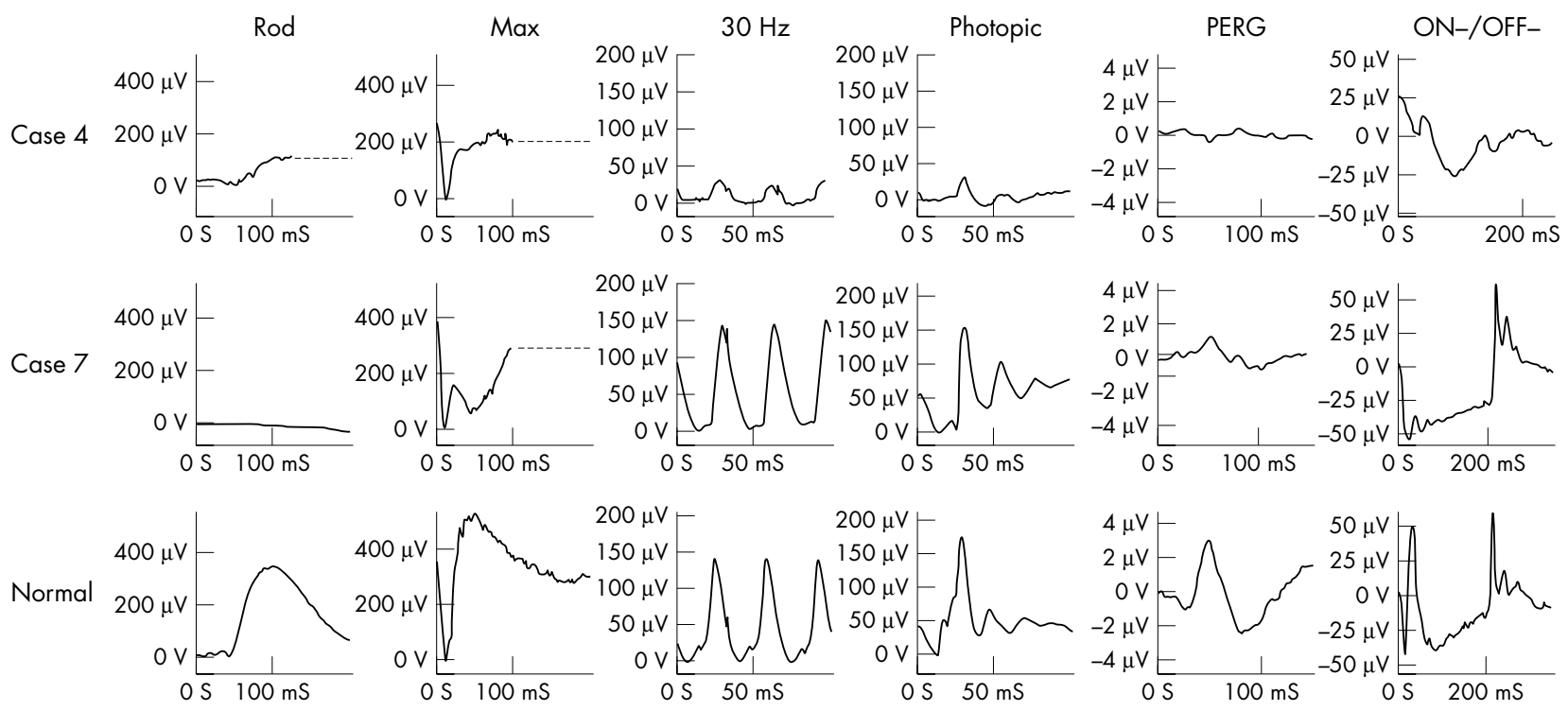

Figure 2 Electrophysiological findings in the left eye of case 4 and right eye of case 7 (see text for details). ON-OFF ERGs were elicited using stimulus duration $120 \mathrm{~ms}$ (case 4) and $200 \mathrm{~ms}$ (case 7 and normal). For clarity, blink artefacts occurring after the ERGs have been replaced by broken lines. 


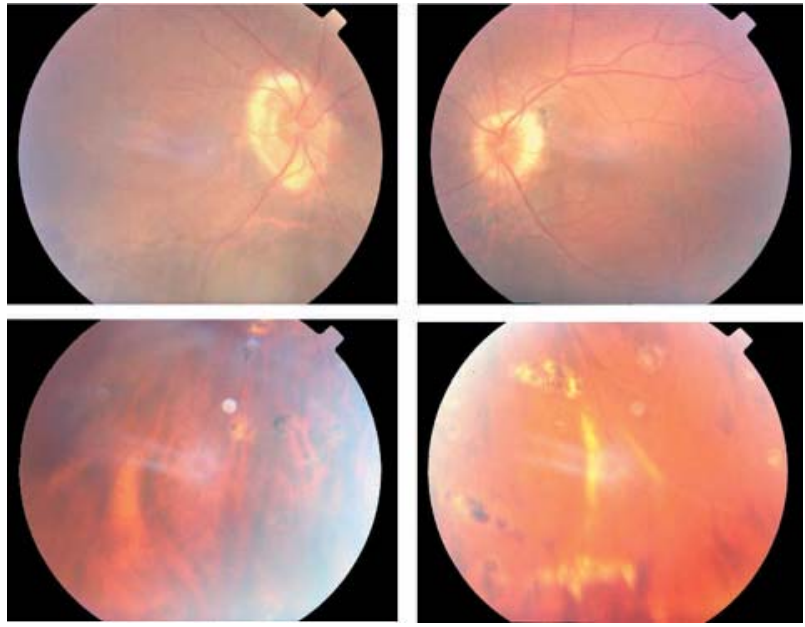

Figure 3 Fundus photographs of case 10 showing chorioretinal scarring in the periphery.

The right eye ERGs (fig 2) showed an electronegative maximal response indicating dysfunction at a level that is post-phototransduction or post-receptoral. The $30 \mathrm{~Hz}$ flicker ERG was reduced and delayed with a flattened trough between adjacent peaks; single flash photopic ERG shows a broadened, bifid a-wave with a sharply rising b-wave. This photopic ERG appearance is often associated with loss of ON pathway function, but preservation of OFF pathway function, and this was confirmed by the use of photopic ON and OFF response recording. There was significant macular involvement shown by the reduced PERG. There was no evidence of dysfunction on the left (not shown). Repeat testing 10 months later revealed no significant change. There has been a recurrence of low grade uveitis since electrophysiology was last performed.

\section{Case 10}

A 31 year old man presented with a 2 year history of decreased acuity in his right eye. VA was 6/60 right, 6/5 left. There was bilateral disc swelling with occasional vitreous cells on the right, and chorioretinal scars (fig 3). There was no RAPD. Fields showed marked enlargement of the blind spot bilaterally. Magnetic resonance imaging scan was normal. Colour vision testing with Ishihara plates gave scores of 1/17 and 17/17 (right and left); colour contrast thresholds were profoundly elevated on the right along protan, deutan and tritan axes; thresholds along protan and deutan axes were normal on the left with mild elevation along the tritan axis.

ERG studies on the right initially revealed rod ERG and maximal ERG a-wave reduction, delayed $30 \mathrm{~Hz}$ ERGs and delayed and reduced photopic transient ERGs. The findings indicate generalised retinal dysfunction affecting the rod and cone systems, primarily at the level of the photoreceptors with involvement of cone ON and OFF responses (fig 4). The PERG was initially present but of markedly reduced amplitude, suggesting moderately severe right macular dysfunction.

Full field ERGs from the left eye (fig 4) showed ON pathway involvement in both rod and cone systems (electronegative maximal response and cone $\mathrm{ON}$ b-wave loss). The PERG was consistent with macular dysfunction, less severe than on the right. The EOG revealed generalised dysfunction affecting the photoreceptor/RPE interface bilaterally, worse on the right (not shown).

Four years after presentation there were vitreous cells and vessel sheathing bilaterally. The right eye developed an epiretinal membrane, the left eye developed mild macular oedema. There were increasing areas of peripapillary atrophy bilaterally. Photopsia was reported on the left, without significant acuity reduction. Over this period there was slight deterioration in full field ERGs; PERG also deteriorated but left visual acuity remained normal. Following treatment with prednisolone and Diamox, full field ERGs remained stable and the left PERG normalised.

\section{Case 12}

A 54 year old woman presented with a 3 month history of unilateral night blindness. There was a 10 year history of chronic bilateral intermediate uveitis. There had been a recent flare up of uveitis with right CMO, successfully treated with post-sub-Tenon's injection of steroids. Visual acuities were $6 / 6$ bilaterally. There were inactive chorioretinal lesions and snowballs scattered across the inferior periphery of both
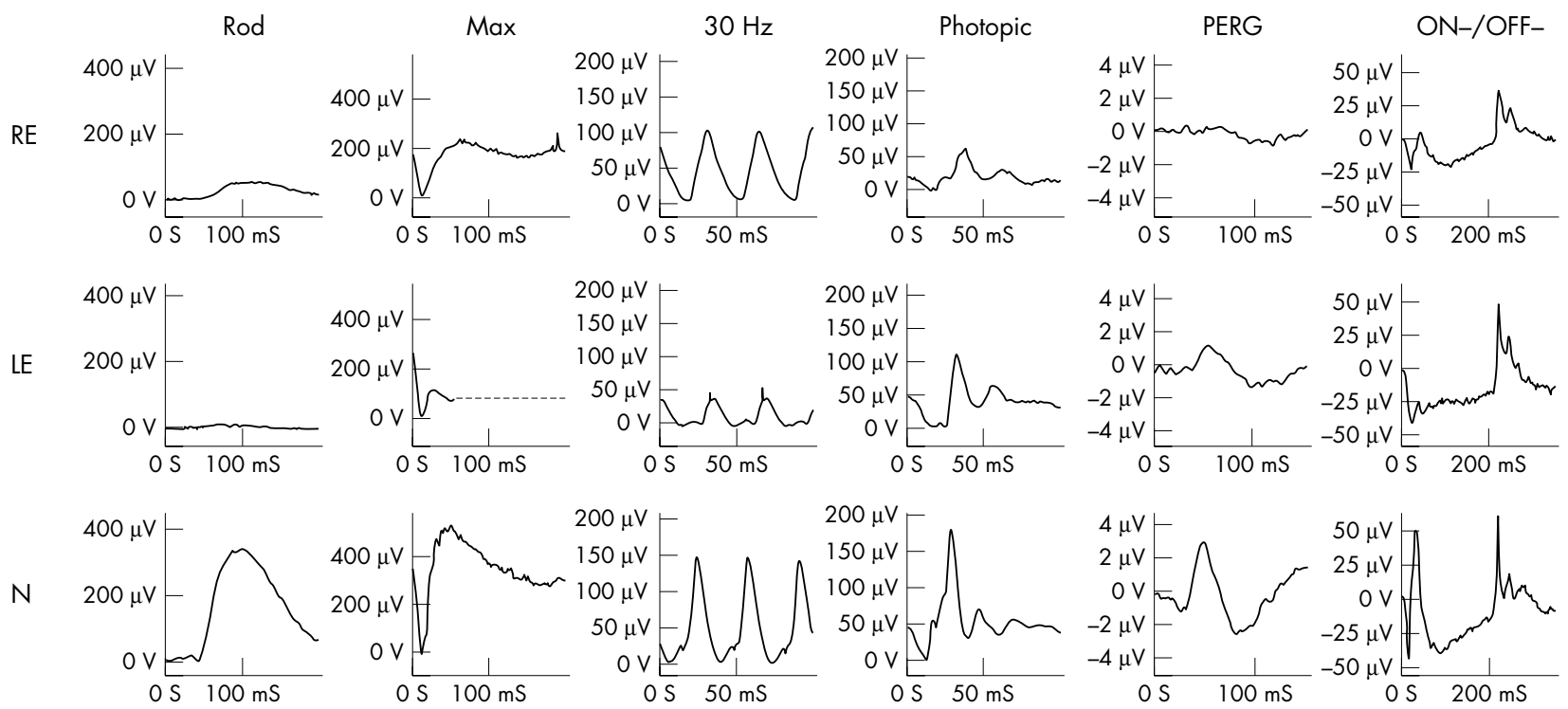

Figure 4 Electrophysiological findings in case 10 (see text for details). ON-OFF ERGs were elicited using stimulus duration 200 ms. For clarity, blink artefacts occurring after the ERGs have been replaced by broken lines. 

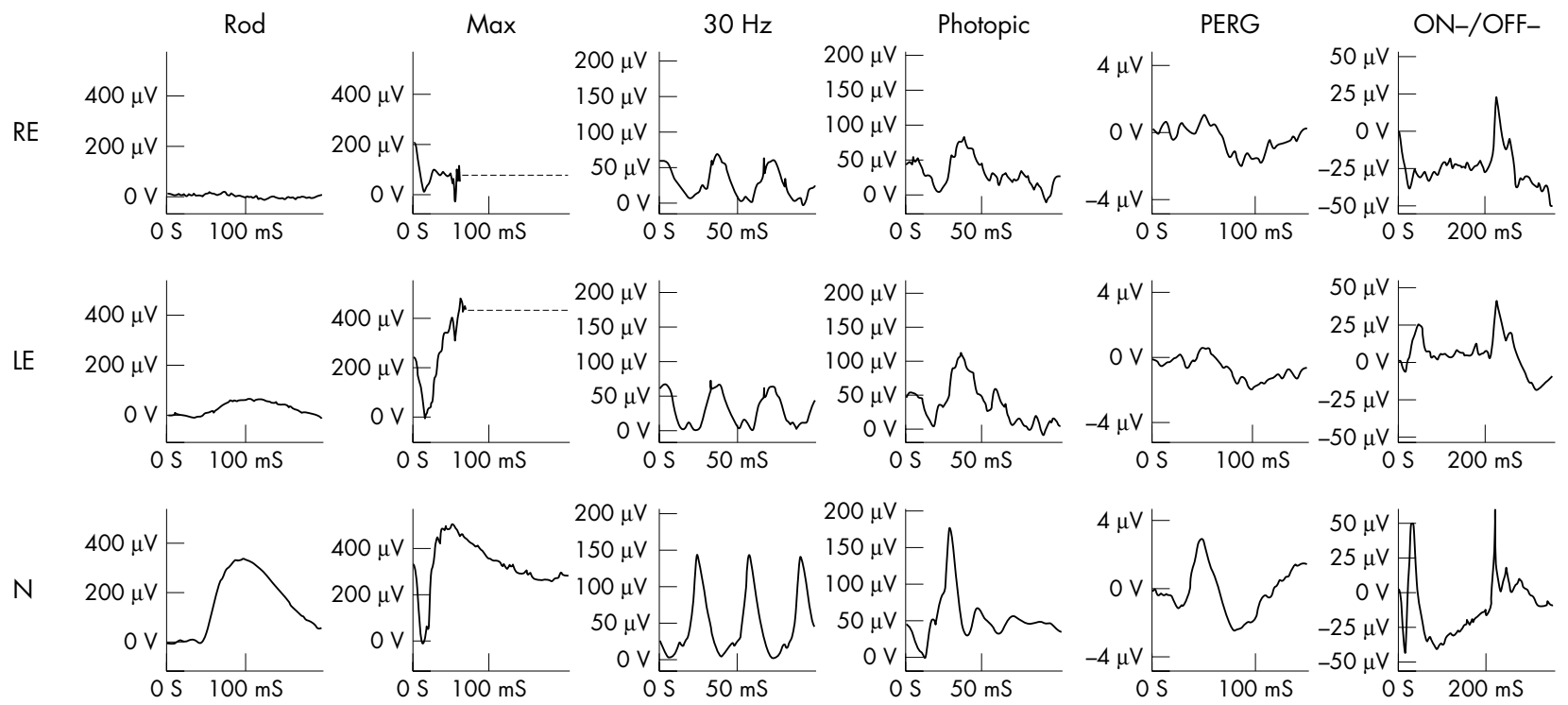

Figure 5 Electrophysiological findings in case 12 (see text for details). ON-OFF ERGs were elicited using stimulus duration 200 ms. For clarity, blink artefacts occurring after the ERGs have been replaced by broken lines.

eyes. In addition, the left eye showed significant vitritis, vascular sheathing, and a peripapillary chorioretinal scar as a result of a choroidal neovascular membrane.

The $30 \mathrm{~Hz}$ flicker ERGs were reasonably symmetrical, markedly delayed but without significant amplitude reduction, in keeping with non-specific bilateral inflammatory disease (Holder 2001), but only the night blind right eye had an electronegative ERG and selective reduction in the ON bwave (fig 5). Reduced PERGs were consistent with bilateral macular dysfunction.

\section{DISCUSSION}

A unilateral "negative" ERG, not related to occlusive vascular disease or birdshot chorioretinopathy, is uncommon. Twelve such patients are described who were ascertained as an extension of a large retrospective study into electronegative ERGs, in which seven such cases were identified. ${ }^{21}$ The patients presented with a variety of signs and symptoms. Posterior segment inflammatory changes were evident in seven of the 12 cases and in six of these cases inflammatory signs or symptoms were either confined to the eye with an electronegative ERG or were more severe in this eye. In one patient (case 10) there were bilateral inflammatory changes associated with an electronegative ERG in one eye. There were ERG abnormalities in the other eye indicating generalised retinal dysfunction affecting rod and cone systems (fig 4), primarily at the level of the photoreceptors, associated with a longer history, and chorioretinal scarring (fig 3). Selective involvement of the retinal ON bipolar pathway was present in the majority of cases.

The clinical presentation of the patients in our series was diverse. Most presented with loss of acuity, blurred or distorted vision, or altered colour vision. Although difficulty in dim lighting was admitted by some patients on direct questioning, it was not usually a presenting symptom. However, one patient with a 10 year history of recurrent intermediate uveitis developed unilateral problems with night vision 3 months before ERG testing (case 12).

Previous reports have appeared of patients with acquired unilateral night blindness, normal fundi, raised rod thresholds and unilateral negative ERGs, ${ }^{30}$ including one case in which ON-OFF ERGs were additionally performed. ${ }^{31} 32$ Similar findings were present in case 7 , who also developed unilateral night blindness. The negative ERG, reduced ON bwave and other unilateral electrophysiological abnormalities in these patients are qualitatively identical to those seen (bilaterally) in "complete" X linked CSNB ${ }^{3}$ and MAR. ${ }^{3} 161731$ Similar bilateral changes can occasionally occur in association with carcinoma associated retinopathy (CAR; Holder, unpublished observations), although CAR more commonly affects photoreceptor function and rarely gives a negative ERG. Both CAR and MAR are paraneoplastic retinopathies in which antibodies produced in response to a tumour antigen cross react with elements in the retina. The characteristic ONOFF ERG abnormalities of MAR can be induced in monkeys by intravitreal injection of IgG from a patient with MAR. ${ }^{33}$ Immunohistochemistry using sera from MAR patients shows selective labelling of rod bipolar cells in human retina ${ }^{34}$ and there is reduced density of the bipolar cell layer in postmortem specimens from MAR patients. ${ }^{35}$ It is of interest that although one patient in the present series had a history of cutaneous melanoma, the findings in that patient involved both $\mathrm{ON}$ and OFF pathways and were not in keeping with MAR (case 2).

Autoimmune retinopathy has been postulated as a cause for severe visual loss and photopsia in two patients with no signs of ocular inflammation or systemic malignancy. ${ }^{36}$ Both patients had evidence of a familial immune regulation defect and in one of these cases ERGs were bilaterally electronegative but more severely abnormal in one eye. Both patients' sera had antiretinal antibodies that localised to the inner plexiform layer. The progression of the visual loss was much slower than that in CAR and was asymmetrical. Anterior segment inflammation has been previously described in a patient with acquired unilateral nyctalopia, photopsia, and visual loss with no history of malignancy. ${ }^{37}$ That patient also had a unilateral negative ERG with selective involvement of the ON response (similar to our cases 7 and 12).

The mechanisms underlying the functional changes in these patients are not established but the high incidence of previous inflammatory disease in affected eyes is noted, as is the predilection for $\mathrm{ON}$ response $\mathrm{b}$-wave loss and OFF response sparing. Five of seven patients with evidence of inflammatory disease had selective or predominant dysfunction of the cone ON response. This association between 
functional disruption of the ON response and a history of unilateral or asymmetrical ocular inflammation possibly involves an autoimmune reaction. The target site of the autoimmune reaction in the retina remains unclear but, as in MAR, is post-transduction and may be the bipolar cell or its connections. Antibodies may be directed towards antigens, disrupting signalling through the bipolar cell layer, or inflammatory changes may cause damage with subsequent exposure of antigens leading to secondary antibody production. $^{37}$

In summary, a unilateral negative ERG in the absence of an occlusive vascular aetiology or BCR is an unusual finding and often associated with sparing of inner retinal OFF response function. Patients present with diverse symptoms and signs but the high incidence of previous inflammatory disease raises the possibility that the electrophysiological changes are mediated by autoimmune mechanisms. Additional studies, testing serum against retinal tissue, may assist in confirming a possible autoimmune aetiology.

\section{ACKNOWLEDGEMENTS}

The Foundation Fighting Blindness (AGR).

\section{Authors' affiliations}

A G Robson, A H C Koh, A Calcagni, G E Holder, Electrophysiology, Moorfields Eye Hospital, London, UK

E C Richardson, C E Pavesio, P G Hykin, Medical Retina Service,

Moorfields Eye Hospital, London, UK

E M Graham, Ophthalmology, St Thomas's Hospital, Lambeth Palace Road, London, UK

\section{REFERENCES}

1 Heckinlively JR, Arden GB. Principles and practice of clinical electrophysiology of vision. St Lovis: Mosby Year Book, 1991.

2 Fishman GA, Birch DG, Holder GE, et al. Electrophysiologic testing in disorders of the retina, optic nerve and visual pathway. 2 nd ed. Ophthalmology Monographs No 2. San Francisco: The Foundation of the American American Academy of Ophthalmology, 2001.

3 Holder GE. Pattern ERG and an integrated approach to visual pathway diagnosis. Prog Retin Eye Res 2001;20:531-61.

4 Miyake Y, Sushiroyama N, Horiguchi M, et al. Bull's eye maculopathy and the negative electroretinogram. Retina 1989;9:210-15.

5 Kellner U, Foerster MH. Cone dystrophies with negative photopic electroretinogram. Br J Ophthalmol 1993;77:404-9.

6 Kellner U, Brummer S, Foerstert MH, et al. X-linked congenital retinoschisis. Graefes Arch Clin Exp Ophthalmol 1990;228:432-7.

7 Bradshaw K, George N, Moore A, et al. Mutations of the XLRS1 gene cause abnormalities of photoreceptor as well as inner retinal responses of the ERG. Doc Ophthalmol 1999;98:153-73.

8 Miyake $Y$, Yagasaki K, Horiguchi $M$, et al. Congenital stationary night blindness with negative electroretinogram. Arch Ophthalmol 1986; 104:1013-20

9 Noble KG, Carr RE, Siegel IM, et al. Autosomal dominant congenital stationary night blindness and normal fundus with with an electronegative ERG. Am J Ophthalmol 1990;109:44-8.
10 Henkes HE. Electroretinography in circulatory disturbances of the retina: electroretinogram in cases of occlusion of the central retinal artery or one of its branches. Arch Ophthalmol 1954;52:42-53.

11 Karpe G, Ucherman A. The clinical electroretinogram. VII: The electroretinogram in circulatory disturbances of the retina. Acta Ophthalmol 1955;33:493-516.

12 Yotsukura J, Adach-Usami E. Correlation of electroretinographic changes with visual prognosis in central retinal artery occlusion. Ophthalmologica 1993;207:13-18.

13 Priem HA, De Rouck, De Laey J, et al. Electrophysiologic studies in birdshot chorioretinopathy. Am J Ophthalmol 1988;106:430-6.

14 Hirose T, Katsumi O, Pruett RC, et al. Retinal function in birdshot retinochoroidopathy. Acta Ophthalmol 1991;69:327-37.

15 Holder GE, Robson AG, Pavesio C, et al. Electrophysiological characterisation and monitoring in the management of birdshot chorioretinopathy. Br J Ophthalmol 2005;89:709-18.

16 Berson EL, Lessell S. Paraneoplastic night blindness with malignant melanoma. Am J Ophthalmol 1988;106:307-11.

17 Alexander KR, Fishman GA, Peachey NS, et al. ON response defect in paraneoplastic night blindness with cutaneous malignant melanoma. Invest Ophthalmol Vis Sci 1992;33:477-83

18 Bacon P, Spalton DJ, Smith SE. Blindness from quinine toxicity. Br J Ophthalmol 1988;72:219-224.

19 Treichel JL, Murray TG, Lewandowski MF, et al. Retinal toxicity in methanol poisoning. Retina 2004;24:309-12.

20 Kaplan HJ, Aaberg TM. Birdshot retinochoroidopathy. Am J Ophthalmol 1980;90:773-782.

21 Koh AH, Hogg CR, Holder GE. The incidence of negative ERG in clinical practice. Doc Ophthalmol 2001;102:19-30.

22 Marmor MF, Holder GE, Seeliger MW, et al. Standard for clinical electroretinography (2004 update). Doc Ophthalmol 2004;108:107-14.

23 Bach M, Hawlina M, Holder GE, et al. Standard for pattern electroretinography. Doc Ophthalmol 2000;101:11-18.

24 Marmor MF, Zrenner E. Standard for clinical electro-oculography. Doc Ophthalmol 1993;85:115-24.

25 Arden GB, Kelsey JH. Changes produced by light in the standing potential of the human eye. J Physiol 1962;161:189-204.

26 Sieving PA. Photopic ON and OFF-pathway abnormalities in retinal dystrophies. Trans Am Ophthalmol Soc 1993;91:701-73.

27 Spileers W, Falcao-Rewis F, Smithi R, et al. The human ERG evoked by a Ganzfield stimulator powered by red and green light emitting diodes. Clin Vis Sci 1993:8:21-38.

28 Calcagni A, Hogg CR, Spackman L, et al. Characterisation of the normal photopic electroretinographic responses to long duration stimuli evoked by a light emitting diode stimulator. Clin Neurophysiol 2001;112:1964-6.

29 Arden GB, Gunduz K, Perry S. Colour vision testing with a computer graphics system. Clin Vis Sci 1988;2:303-20.

30 Ayaki M, Oguchi Y, Matsuhashi M. Unilateral night blindness with a normal fundus. Am J Ophthalmol 1984;98:630-2.

31 Fishman GA, Alexander KR, Milam AH, et al. Acquired unilateral night blindness associated with negative electroretinogram waveform. Ophthalmology 1996;103:96-104.

32 Barnes CS, Brigell MG, Alexander KR. ON-pathway dysfunction in a patient with acquired unilateral night blindness. Retina 1998; 18:531-8.

33 Lei B, Bush RA, Milam AH, et al. Human melanoma-associated retinopathy (MAR) antibodies alter the retinal ON-response of the monkey ERG in vivo. Invest Ophthalmol Vis Sci 2000:41:262-6.

34 Milam AH, Saari JC, Jacobson SG, et al. Autoantibodies against retinal bipolar cells in cutaneous melanoma-associated retinopathy. Invest Ophthalmol Vis Sci 1993;34:91-100.

35 Gittinger JW, Smith TW. Cutaneous melanoma-associated paraneoplastic retinopathy: histopathologic observations. Am J Ophthalmol 1999;127:612-14

36 Mizener JB, Kimura AE, Adamus $G$, et al. Autoimmune retinopathy in the absence of cancer. Am J Ophthalmol 1997;123:607-8.

37 Murayama K, Kawabata H, Adachi-Usami E. An electrophysiological followup study on acquired unilateral nyctalopia. Eye 1999;13:629-34. 